Extrême-Orient Extrême-Occident

\section{Extrême-Orient Extrême-Occident}

35 | 2013

Les astres et le destin. Astrologie et divination en Asie orientale

\title{
Astrology and Hemerology in Traditional Vietnam
}

Astrologie et hémérologie dans le Viêt-Nam traditionnel

\section{Alexei Volkov}

\section{(2) OpenEdition}

\section{Journals}

Electronic version

URL: http://journals.openedition.org/extremeorient/282

DOI: 10.4000/extremeorient.282

ISSN: 2108-7105

Publisher

Presses universitaires de Vincennes

\section{Printed version}

Date of publication: 1 May 2013

Number of pages: 113-140

ISBN: 978-2-84292-367-9

ISSN: 0754-5010

Electronic reference

Alexei Volkov, " Astrology and Hemerology in Traditional Vietnam », Extrême-Orient Extrême-Occident

[Online], 35 | 2013, Online since 01 May 2016, connection on 19 April 2019. URL : http://

journals.openedition.org/extremeorient/282 ; DOI : 10.4000/extremeorient.282 


\title{
Astrology and Hemerology in Traditional Vietnam
}

\author{
Alexei Volkov ${ }^{1}$
}

\section{Introduction: historical background}

The northern part of present-day Vietnam formally became a province of the Chinese Han Empire in the late 2nd century BC, yet intellectual exchanges between this region and other parts of China had existed long before that time. When Vietnam ceased to be a Chinese province in the 10th century AD, the newly born Vietnamese state implemented a bureaucratic system similar to that of the Chinese Song dynasty (960-1279), including educational institutions and the examination system. Chinese cultural influence remained strong throughout subsequent Vietnamese dynasties, and became even stronger during and after the short-term Chinese occupation of Vietnam in 1407-1427. The French colonization that started with the Cochinchina campaign in 1858-1862 marked the beginning of a rapid decline of traditional Sino-Vietnamese scholarship, and the decisive coup de grâce was delivered by the abolishment of the state examination system in 1919.

During the period that Vietnam was a full-fledged province of the Chinese empire (now often referred to by Vietnamese authors as the period of "Chinese domination"), local government used classical Chinese for official documents, education, and state examinations. The earliest documents (inscriptions on stone steles of the first millennium AD) contain none, or very few, of the "local" characters designed on the basis of Chinese script. After the separation of Vietnam from China in the 10th century, an increasing number of local characters

1. The study of the Vietnamese treatises discussed in this paper was supported by the research grants 95-2411-H-007-037 (in 2006-2007) and 96-2411-H-007-004-MY3 (in 2007-2012) of the National Science Council (Taiwan), as well as by a grant from the Project "Multiculturalism in Monsoon Asia" (National Tsing-Hua University, Hsinchu, Taiwan) in 2008-2012. The author is grateful to two anonymous reviewers for helpful comments on the first draft of this paper. 
appear in written documents. The local script designed on the basis of Chinese characters and used to record the Vietnamese language is known as Nôm 喃. ${ }^{2}$ Several times Vietnamese rulers made attempts to use Nôm as the language of official documentation and of scholarship instead of classical Chinese (Hán 漢), but classical Chinese remained more often used. Nowadays the term "Hán-Nôm 漢喃 books" is used to refer to the entire corpus of Vietnamese books written in classical Chinese or in Vietnamese (using Nôm characters), or in a mixture of both. ${ }^{3}$

In the late 19th century, the French colonial government systematically eradicated the traditional Hán-Nôm writing system partly naively misunderstood and partly intentionally interpreted by the proponents of French colonization as a sign of the political and cultural domination of China over Vietnam. The use of a phonetic writing system using Latin letters with diacritical signs designed by Catholic missionaries in the late 16th and early 17th century (nowadays, paradoxically, referred to in Vietnam as Quốc Ngũ 國語, "national language”) was originally suggested as a solution for problems arising from the difficulties experienced by functionaries of the French colonial administration when using Vietnamese. At the same time, it was perceived as a means to eradicate dependence on the Chinese-style education system and, ultimately, to replace it by modern French education. ${ }^{4}$ The Vietnamese anti-colonial movements gaining momentum in the early 20th century also championed the alphabetic script Quốc $N g \tilde{u}$ as important for national liberation and for the rapid modernization of the

2. For a detailed description of the history and main features of Nôm see Lê 1995; on pages 93-96 of this dissertation the reader will find numerous references to relevant publications in Vietnamese and in French. For publications in English see, for example, Nguyễn 1956; 1990.

3. Here and everywhere in this paper I provide Vietnamese readings of the Hán-Nôm characters; Chinese readings of them in the pinyin transliteration system, when provided, are marked with the word "Chinese." The titles of Chinese books and names of Chinese authors are provided in the pinyin transliteration system without their Hán-Nôm reading.

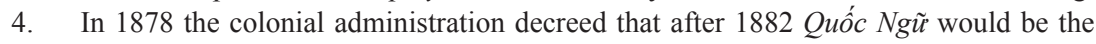
only official form of writing, apart from French; see Osborne 1997: 163. However, as was promptly suggested by the anonymous reviewers of the present paper, the stand taken by the French colonial authorities and by the Vietnamese literati concerning the instruction of, and in, Quốc Ngũu, went through considerable modifications in the early 20 th century. Unfortunately, a detailed discussion of this fascinating topic would not be relevant here; the interested reader is referred to Marr 1981, Osborn 1997, Poisson 2004, and Trinh 1995, among others. 
country. ${ }^{5}$ Later, when instruction of and in French was interrupted (in the 1940s in the North) or reduced (in the South), the Quốc Ngũ script eventually became the only written language used by the Vietnamese ethnic majority group, Kinh (or Viẹt, nowadays constituting ca. $85 \%$ of the entire population). As a result, the literary heritage of more than ten centuries of the independent development of the nation was lost in just a few decades, and today only a few individuals are capable of reading old texts written in Hán-Nôm script. Moreover, during the wars that took place in Vietnam in the 20th century, the books preserved in the Imperial Library in Huế as well as in private collections were damaged, destroyed, or lost. As far as the books on divination are concerned, in 1948-49, 1956, 1968, and 1976 the Vietnamese government conducted several campaigns aiming at the eradication of "superstitions," in particular divination, during which the tools and books used by professional diviners were confiscated. ${ }^{6}$ To conclude, in Vietnam in the past several decades a large number of books related to divination were lost, destroyed, or became unavailable to researchers.

\section{Vietnamese astrology: secondary literature and primary sources}

The history of divination practiced by the majority ethnic group Kinh has, to my knowledge, never been systematically discussed in publications in Western languages. ${ }^{7}$ The first attempts to study and to describe Vietnamese literary sources as well as the actual practices of diviners were made by the French colonial scholars Gustave Dumoutier (1850-1904) and Georges Coulet (active in the 1920s). ${ }^{8}$ An introduction to Vietnamese civilization written for a general audience by Nguyen Van Huyen very briefly mentions several kinds of divination, in particular those related to mediumistic practices. ${ }^{9}$ Huard and Durand (1954) present an outline of Vietnamese divination (in this case apparently referring to the divination of the Kinh, since the authors never mention any minority groups); they list geomancy, astrology, "sorcery," physiognomy, and "zoochiromancy" as the most widely practiced forms of divination. ${ }^{10}$ The Chinese origin of the Vietnamese tradition of divination is not discussed by Huard and Durand, but

5. As D. Marr put it, "By the 1930s the idea that quoc ngu development and dissemination constituted essential components of the struggle for independence and freedom was part of every radical [anti-colonial] platform." (Marr 1981: 150)

6. Văn 2008: 266-267.

7. On the mantic techniques used by some ethnic minorities in Vietnam see, for example, Arhem 2009; Vargyas 2004.

8. Dumouutier 1899; 1914; 1915; Coulet 1926; 1929.

9. Nguyen 2002: 245-256.

10. Huard et Durand 1954: 65-71. 
they do mention the astrological treatise Zi wei dou shu quan shu (Vietnamese Tủ vi đẩu số toàn thu) 紫微斗數全書 by the Chinese author Chen Tuan 陳摶 (also known as Chen Xiyi 陳希夷, 871-989) as the most popular divination manual in Vietnam. ${ }^{11}$

The extant treatises on divination can be found listed in two standard catalogues of Hán-Nôm books. One of them is a bilingual (Vietnamese and French) catalogue by Trần Nghĩa and François Gros (1993), and the other is a catalogue compiled (in Chinese) by Liu Chun-Yin 劉春銀, Wang Xiaodun 王小盾 and Trần Nghĩa 陳義 (Liu et al. 2002). The catalogue Trần and Gros (1993) contains 5,038 bibliographical entries listing the holdings of the library of the Institute of Hán-Nôm Studies (Hanoi), the libraries of the École française d'Extrême-Orient (hereafter EFEO) and the Société Asiatique (both in Paris), as well as some Vietnamese and Japanese libraries. Each entry of the catalogue includes short annotations in Vietnamese and in French; the titles of the books are listed in alphabetical order according to the transliteration system Quốc $n g \tilde{u}$. To identify books on divination, one can use an index provided at the end of the catalogue. The books on astrology are found in the subsection Tín nguõng dân gian (Traditional beliefs) which contains references to books belonging to a wide variety of disciplines, from "anthropology" and "religion" to "literature." This classification system makes it difficult to identify books related specifically to astrology. The catalogue of Liu et al. (2002) is based on the catalogue Trần and Gros (1993), but the bibliographical entries in it are reorganized according to the traditional Chinese system of "four categories" ("canonical books" 經, "historical compilations" 史, "philosophical schools" 子, and "literary collections" 集). Books on divination are found in the section "numerology" (shushu 數術) of the category "philosophical schools" and are subdivided into five categories: geomancy (kanyu 堪輿), astrology (xingming 星命), divination based on hexagrams of the Yijing (Yigua 易卦), physiognomy and [related (?)] miscellaneous types of divination (xiangfa zazhan 相法雜 占), and "tallies and omens" (qianchen 籤識). However, a cursory inspection of the section bingjia 兵家 (Military arts) of Liu et al. (2002) shows that it

11. Huard and Durand 1954: 66. There are numerous copies of the book entitled Tủ Vi Đẩu Số 紫微斗數 preserved in the library of the Institute of Hán-Nôm Studies (Hanoi) as well as in the library of the Société Asiatique (Paris) (see item [A47] in the bibliography at the end of this paper), but I was unable to locate any copy of the book Tư vi đẩu số toàn thu mentioned by Huard and Durand. Surprisingly, the authors also claim that the Vietnamese astrologers used the Chinese mathematical encyclopaedia Shu li jing yun 數理精緢 (Vietnamese Số Li Tinh Uẩn) compiled in 1723 under the direction of Mei Juecheng梅歖成 (1681-1763). Compare with the mention of this collection in a Chinese official calendar quoted (but not properly identified) by C. Morgan (1980: 21). 
also contains books whose descriptions suggest that they may feature methods of divination related to military affairs. Similarly, the books devoted to the Yijing in the category of "canonical books" 經 and some medical treatises contain descriptions of mantic procedures or discussions of the philosophical and theoretical foundations of divination.

Both catalogues Trần and Gros (1993) and Liu et al. (2002) do not list the books preserved in several large collections holding texts on astrology. ${ }^{12}$ There is also reason to believe that a number of Hán-Nôm books on astrology from the Imperial library in Hue are still extant; unfortunately, they are preserved in private collections and therefore remain unavailable for systematic study. The overview of the primary materials presented in this paper will thus necessarily be incomplete.

\section{Vietnamese astronomical and astrological facilities: an overview}

According to the [Đại] Việt sủ lược [大]越史略 (An abridgement of the history of the [Great state of] Viet) that covers the period from the 2nd century $\mathrm{BC}$ to the year 1225 and is considered by some historians the oldest extant Vietnamese chronicle, ${ }^{13}$ the Vietnamese rulers started building astronomical/ astrological facilities in the capital Thăng Long 昇龍 (i.e. modern Hanoi) as early as 1029, when the second Emperor of the (Later) Lý Dynasty (後)李朝 (10091225), Thái Tông 太宗 (personal name Lý Phật Mã 李佛瑪, r. 1028-1054), ordered to rebuild the palace Càn Nguyên Điện 乾元殿 after the earthquake of $1017 ;{ }^{14}$ the newly built facilities included the Pavilion of Paying Tribute to Heaven (Phung Thiên Điện 奉天殿) on the top of which was placed a Noon Tower (Chính Duoong Lâu 正陽樓) with a clepsydra clock inside. ${ }^{15}$ It appears

12. Such as the collection of the National Library (Hanoi) as well as some smaller collections, for example, that of the Institute of History of the Academy of Social Sciences of Vietnam. My inspection of the two latter libraries undertaken in 1998-2008 showed that they held a number of texts on divination (including astrology) not catalogued in Trần and Gros (1993) or in Liu et al. (2002).

13. The [Đại] Việt sử lược [SL 1936] contains an addendum entitled "Chronology of the Trần 陳 dynasty" that covers the period from 1225 to 1377; L. Cadière and P. Pelliot (1904: 626) used this fact to conclude that the chronicle was compiled during the reign of the Trần Emperor Phế Đế 廢帝 (personal name Trần Hiện 陳晛, r. 1377-1388). However A. Polyakov, on the basis of his textual analysis of the chronicle, convincingly argues that its first two chapters were compiled in the early 12th century (Polyakov 1980: 74).

14. SL 1936: 27; Polyakov 1980: 143.

15. The relevant record in the [Đai ] Việt sủ luợc [大]越史略 reads: 前安奉天殿。上建 正陽樓。為掌漏刻之處。 [SL 1936: 29], that is, “In front [of the Dragon Stairs 龍 墀, the King] set the Pavilion of Paying Tribute to Heaven. On the top [of it he] built 
quite probable that astronomical and astrological observations at the courts of the Vietnamese rulers may have started even earlier, in the late 10th century, almost immediately after Vietnam gained its independence from China. The moment in time when the first observations were conducted can be approximately calculated on the basis of the records of solar eclipses (see below).

In 1206 this astronomical facility was damaged by fire, and it was restored only some time later ${ }^{16}$ which, theoretically, may be the reason why the Vietnamese chronicles [Đại] Việt sử lược and Đại Việt sủ ký toàn thu 大越史 記全書 (Complete Annals of the great [state of] Việt) do not contain records of the eclipses that occurred between 1206 and $1242 .{ }^{17}$ Two facilities most likely related to astronomical and astrological activities are depicted as located near the Palace in a 17th century copy of the atlas Hồng Đúc Bản Đồ 洪德版圖 (Maps [of Vietnam] printed [in the era] "Overwhelming virtue") of 1490 (Fig. 1), ${ }^{18}$ they are the "Office of Paying Tribute to Heaven" (Phung Thiên Phu 奉天府) and the "Directorate of Heavenly Affairs" (Ti Thiên Giám 司天監, Chinese Si tian jian). ${ }^{19}$

the Noon Tower. [It] was the place to operate the clepsydra"; see also a translation in Polyakov [1980: 147]. This event is described in the Đại Việt sủ ký toàn thu大越史記 全書 in slightly different terms: “前安奉天殿。上建正陽樓。以為主掌薵刻之處” [TT 1984: 221]. If the word 籌 was not a copyist's mistake, it may have referred to the counting rods used for astronomical computations. These counting rods were used by Vietnamese astronomers until the 17th century or even later; see Volkov 2009.

16. SL 1936: 61; Polyakov 1980: 206.

17. The chronicles do not mention the annular eclipse of August 4th 1217, visible in Northern Vietnam, or the eclipse on May 23rd 1221, visible in China and in Northern Vietnam. The [Đại] Việt sử lược does not contain any relevant information dated after 1225, and the Đại Việt sư ký toàn thu 大越史記全書 does not mention the eclipses that occurred on July 3rd 1228 and December 19th 1237. The eclipse of 1229 mentioned in the Đai Việt sủ ký toàn thur (Ho 1964: 139, no. 34) is fictitious; the earliest actual eclipse among those listed in the latter chronicle as having occurred in the 13th century is that of September 26th 1242 (ibid., no. 35). Information about these and other solar eclipses is taken from the NASA webpage "Eclipse Predictions by Fred Espenak, NASA's GSFC" at http://eclipse.gsfc.nasa.gov/SEatlas/SEatlas.html.

18. The replacement of the taboo characters 邦 and 新 (used in the personal names of the Vietnamese emperors Anh Tông 英宗, personal name Lê Duy Bang 黎維邦, r. 15571572, and Kính Tông 敬宗, personal name Lê Duy Tân 黎維新, r. 1600-1618) in the extant atlas suggests that it is not an exact copy of the original edition but its later modified version, see Liu et al. 2002: 305. John. K. Whitmore (1995: 486) provides additional details suggesting that the extant atlas is a 17 th century re-edition of the 15 th century prototype; see also Papin 2001: 123-124.

19. For the homonymous Chinese prototype of this institution, Si tian jian 司天監, Hucker (1985: 456) suggests "Directorate of Astronomy"; this rendering might imply that this 


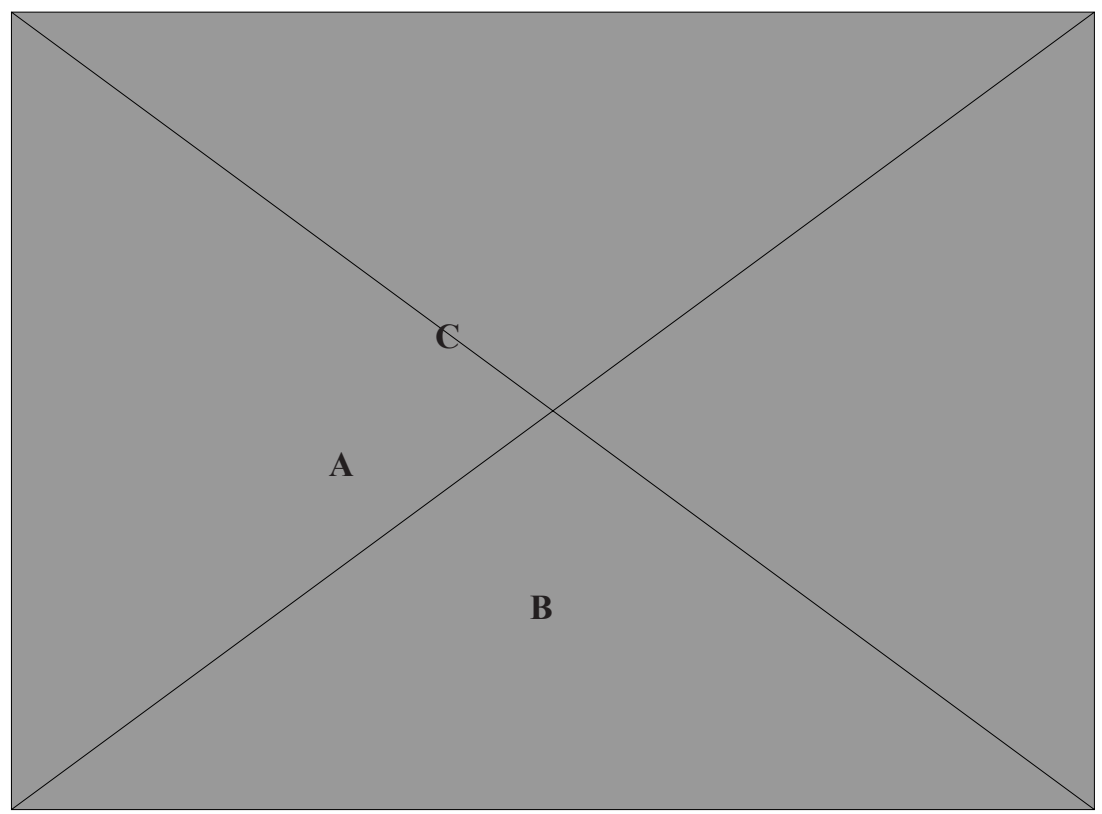

Fig. 1. The map of Hanoi from the Hồng Đúc Bản Đồ 洪德版圖

(the West is at the top) showing the locations of the "Directorate of Heavenly Affairs" Ti Thiên Giám 司天監 (A), the “Office of Paying Tribute to Heaven” Phụng Thiên Phủ 奉天府 (B), and the "Directorate of Education" Quốc tủ giám 國子監 (C).

Even though the name of the "Office of Paying Tribute to Heaven" mentions Heaven and is conspicuously similar to that of the "Pavilion of Paying Tribute to Heaven" (Phụng Thiên Điện 奉天殿) of the (Later) Lý Dynasty, I am currently not aware of any evidence suggesting that the functions of the Office involved time-keeping or other activities related to astronomical observations. The "Directorate of Heavenly Affairs" is depicted on the map as located to the South of the Imperial Palace between the "Office of Paying Tribute to Heaven" and the "Directorate of Education" (Quốc tư giám 國子監, Chinese Guo zi jian), the higher education authority. The name of the former institution, Ti Thiên Giám 司天監, is identical with that of its Chinese counterpart; in China it was given to the Astronomical/Astrological Bureau for the first time in the 10th century

office (literally "Supervising Authority in charge of [matters related to] Heaven") was conducting exclusively astronomical activities, while the institution was actually in charge of observation of all kinds of celestial phenomena (including meteorological ones) and of their interpretation, astronomical as well as astrological. 
and used almost systematically during the Yuan (starting from the 1260s), the Ming, and (unofficially) the Qing dynasties. ${ }^{20}$ The exact time of establishment of the Vietnamese "Directorate of Heavenly Affairs" is not known.

It remains unknown whether the original "Directorate of Heavenly Affairs" of the early 11th century was built in the location shown on the map. It was most likely shut down during the Chinese occupation of 1407-1427, because it would otherwise have challenged the exclusive right of the Chinese official astrologers to conduct and interpret astronomical observations. One can conjecture that the institution was re-opened soon after the retreat of Chinese army, and remained functional throughout the 17th century, when the copy shown in Fig. 1 was produced.

Equally unknown is how exactly the personnel of the astronomical/ astrological service was trained, yet it would be reasonable to conjecture that the Vietnamese authorities established a special educational program to train future astronomers and astrologers, as was the case in China. The Directorate would thus have been responsible for conducting observations, interpreting astronomical and meteorological data, performing computations of the calendar, predicting eclipses, and training future employees. Most likely this institution had a specialized library holding books on astronomy and astrology that were not supposed to circulate outside of the office. An indirect piece of evidence supporting this assumption is found in the Chinese collection of statutes Song hui yao 宋會要: in a record dated 1107 it is mentioned that the Vietnamese envoys to China made attempts to obtain books on various disciplines, and that they were given permission to purchase all texts except those deemed "forbidden," that is, related to divination, yin-yang, the calendar, and numerology; this very mention seems to suggest that the envoys were especially interested in books on these topics. ${ }^{21}$ Attempts to obtain texts related to calendars (and, most likely, astrology) continued through the early 14 th century. ${ }^{22}$

The curriculum of the Chinese School of Computations (Suan xue 算學) of the early 12 th century included a number of subjects directly related to the calendar and to astrology, in particular to the so-called "three schemes" or "three cosmic boards" san shi 三式, that is the three major methods of divination (see below), as well as other unidentified astrological texts. ${ }^{23}$ If astronomical and astrological texts were included in the curriculum of the discipline referred to as "counting" 算 (Vietnamese toán, Chinese suan) in Vietnam, then the

20. Hucker 1985: 456-457, no. 5780.

21. Han 1991: 4. On the restrictions imposed upon the circulation of astronomical and astrological literature during the Tang and Song dynasties see Morgan 1987: 57.

22. Fedorin 2009.

23. Lee 1985: 96; Friedsam 2003: 52. 
state examinations on "counting" mentioned in historical documents may have included parts related to calendrical and astrological computation, as was the case in China during the Song dynasty. ${ }^{24}$ There exist records of state examinations on "counting" held in Vietnam in $1077,{ }^{25} 1261,{ }^{26} 1363,{ }^{27} 1404,{ }^{28}$ $1477,{ }^{29} 1507,{ }^{30}$ and $1762 .{ }^{31}$

Descriptions of the activities of the professional astronomers and astrologers employed by the Vietnamese authorities can be found in the memoirs of the Italian Jesuits Christophoro Borri (1583-1632) and Giovanni Filippo de

24. The anonymous reviewers of this paper rightly pointed out that the description of the examinations on "counting" of 1762 (CM 1996: 3720-3721) mentions problems on flatrate and weighted distribution (Viet. bình phân 平分 and sai phân 差分 respectively) as the topic of the examinations on "counting" (actually, the chronicle mentioned this topic as one among others, yet those "others" were not specified); on distribution problems in Vietnamese mathematics see Volkov 2012, and on administrative activities involving a certain mathematical knowledge, such as land surveying and accounting, see Poisson 2004. This record thus suggests that by the 18th century mathematical and astrological subjects were most probably taught separately; this conjecture may be supported by a record dated to the 7th year of the (Vietnamese) Cảnh Hung 景興 era (1740-1786), that is, 1746 (mentioned in CM 1969 as corresponding to the 11 th year of the (Chinese) Qianlong 乾隆 era, 1735-1796, that is, 1745) concerning examinations conducted exclusively on astrological subjects (CM 1969: 3606). However, the separation of the two curricula apparent in these documents of the mid-18th century does not warrant the conclusion that instruction in mathematics and astrology was always conducted separately; in other words, it cannot be ruled out that at an early stage Vietnamese mathematical instruction imitated the Song dynasty model in which a number of subjects, purely mathematical from a modern viewpoint, were taught together with astronomical and astrological ones, see Lee 1985: 96 and Friedsam 2003: 52.

25. CM 1969: 697.

26. CM 1969: 984.

27. CM 1969: 1292.

28. CM 1969: 1458. In this source the year in question is mentioned as the second year of the Khai Đai 開大 era (1403-1407) of the Hồ 胡 dynasty (1400-1407), that is, 1404, and, at the same time, the second year of the Chinese Yongle 永樂 era (1402-1424), that is, 1403 .

29. CM 1969: 2253, TT 1984: 703; misprinted as "1472" in Han 1991: 6.

30. CM 1969: 2456. The examinations took place in the 12th month of the first year of the Chinese era Zhengde 正德 (1506-1522) and of the second year of the Vietnamese era Đoan Khánh 端慶 (1505-1509); both dates correspond to the beginning of the year 1507.

31. CM 1996: 3720-3721. This record contains the aforementioned description of an examination that took place in the 5 th month of the $23 \mathrm{rd}$ year of the (Vietnamese) Cảnh Hung 景興 era (1740-1786), that is, 1762, mentioned in CM 1969 as corresponding to the 27th year of the (Chinese) Qianlong 乾隆 era, 1735-1796, that is, 1761 . 
Marini (1608-1682), who visited Cochinchina (Central Vietnam) and Tonkin (Northern Vietnam), respectively. Borri's description shows that not only the King of Cochinchina, but also the princes, had their own astrologers whose work included calculation of solar eclipses; de Marini describes a special ritual that was supposed to be conducted by the ruler on the day of the solar eclipse. ${ }^{32}$ These descriptions suggest that by the 17th century the Vietnamese astronomers enjoyed a rather high official status, that they used Chinese methods of prediction of eclipses, and that they sometimes could not correctly adjust these methods to the locations (i.e. northern and central Vietnam) where the eclipses were supposed to be observed.

An official institution responsible for astronomical affairs and the calendar continued to exist in Vietnam until the 20th century. A description (dating to 1930) of the astronomical/astrological office Khâm Thiên Giám 欽天監, the successor of the Ti Thiên Giám 司天監, ${ }^{33}$ describes the structure and personnel of the astronomical/astrological office located in Hue, the capital of the Nguyễn dynasty (1802-1945), and briefly relates its history, beginning from the era of the Emperor Minh Mang (r. 1820-1841). ${ }^{34}$

\section{Astronomical observations conducted in Vietnam}

Ho Peng Yoke in his paper (1964) provided a list of the solar eclipses mentioned in the Đại Việt sử ký toàn thu 大越史記全書 (Complete Annals of the Great [State of] Việt) as observed in Vietnam. Ho's analysis demonstrated that "much of the earlier materials of the Đại Việt sư ký toàn thu were taken from Chinese sources, including their misprints" (p. 128). The records of eclipses in the Annals are not distributed homogenously: there are 21 eclipses for the period from $205 \mathrm{BC}$ to $122 \mathrm{BC}$, one eclipse for each of the years $\mathrm{AD} 41,479$, and $547,{ }^{35}$ and then a series of 45 eclipses for the period from AD 993 to 1671. The records concerning the eclipses from $205 \mathrm{BC}$ to $\mathrm{AD} 547$ were, as Ho suggests, copied from Chinese sources. One is thus tempted to suggest that the beginning of a (relatively) systematic observation of solar eclipses in Vietnam may have

32. Volkov 2008.

33. The name of this institution was identical with the name of its Chinese counterpart, Qin tian jian 欽天監, used during the late Ming and Qing dynasties in China; see Hucker 1985: 169. Hucker translates the name of this institution (meaning literally "Directorate of paying respect to Heaven") as "Directorate of Astronomy," even though his own description makes it clear that the occupations of its staff included meteorological observations and divination.

34. See [KTG].

35. Ho 1964: 138, nos. 22-24, respectively. 
coincided with the establishment of an astronomical/astrological service in the capital. ${ }^{36}$ The above-mentioned [Đai ] Việt sư luoọc [大]越史略 (An Abridgement of the History of the [Great state of] Viet) also contains records of solar eclipses, yet these records are not identical with those listed in the Đại Việt sủ ký toàn thu. More specifically, [Đai ] Việt sủ lược contains records of only five solar eclipses, of which the earliest is dated February 15 th $1040 ;{ }^{37}$ this eclipse, actually visible in Vietnam, is also listed in the Đại Việt sư ký toàn thur. ${ }^{38}$ Interestingly enough, the four remaining eclipses recorded in the [Đai ] Việt sư lượ are not found in the Đai Việt sứ ký toàn thur. Only one of them, the eclipse of March 11th 1206, corresponds to an eclipse that actually happened (even though most likely it was not visible in Vietnam); $;^{39}$ two out of the remaining three eclipses occurred in years slightly different from those indicated in the [Đai ] Việt sứ luợc, ${ }^{40}$ while one record does not correspond to any actual eclipse that might have happened either earlier or later, unless both the month and the year of the eclipse were changed considerably by the compilers of the history or by later copyists. ${ }^{41}$

36. It is possible that the distribution of the eclipses mentioned in the Đại Việt sử ký toàn thu was intentionally brought into correspondance with the political history of Vietnam, because all the recorded eclipses, except those of 479 and 1422, belonged to periods of the formal independence of Vietnam from China: the period from 205 to $122 \mathrm{BC}$ corresponds to the Vietnamese Triệu 趙 dynasty (207-111 BC), the eclipse of AD 41 happened during the rebellion of the Trung 徵 sisters (AD 40-43), and the eclipse of 547 falls within the period of rule of the Vietnamese Early Lý Dynasty (544-602). The eclipse of April 8th 479 was an annular one, visible in India and China and probably hardly noticeable in Vietnam; conversely, the total eclipse of September 20th 461, perfectly visible in Northern Vietnam, was not listed. The eclipse of 23rd January 1422 was not visible in Vietnam either.

37. SL 1936: 30; Polyakov 1980: 149.

38. Ho 1964: 139, no. 29.

39. SL 1936: 61; Polyakov 1980: 206.

40. These two eclipses are: (1) the one on the first day of the 11th month of 1105 (a partial eclipse), see SL 1936: 42, and Polyakov 1980: 173, and (2) the one on the first day of the second month of 1188, see SL 1936: 57, and Polyakov 1980: 198. The former record probably corresponds to the eclipse on December 16th 1107, and the latter to the eclipse on February 17th 1189; both eclipses were visible in Vietnam.

41. The eclipse on the first day of the 10th month of the year 1093; see SL 1936: 41; Polyakov 1980: 170. From 1081 to 1100 there were only two eclipses that might have been visible in Hanoi: one on March 19th 1094, and the other on October 14th 1083. No eclipses were visible in China in this time interval. 


\section{Astrological treatises: introductory remarks}

Astrological treatises preserved in collections of Vietnamese books written in Hán and Nôm are listed in the bibliography found at the end of this paper; the reader can see that in the majority of cases one deals with undated manuscript copies of uncertain origin. The printed books usually bear the dates of publication, and these dates are comparatively recent, from the late 19th to the early 20th century. These late dates of print do not necessarily correspond to the actual time of compilation; however, without substantial evidence to the contrary, it seems reasonable to suggest that most of the extant Vietnamese materials on astrology were physically produced relatively late, even though, hypothetically, they might have been based on earlier sources. This statement does not deny that historically much earlier astrological literature may well have existed in Vietnam. There are two reasons to claim so: firstly, the official institutions dealing with astronomical and astrological matters established in independent Vietnam in the early 11th century must have possessed a number of texts pertaining to their activities; secondly, there are mentions of influential astrological works compiled by Vietnamese scholars which are no longer extant. For example, it is known that Trần Nguyên Đán 陳元旦 (1325-1390), a highlevel advisor to the Vietnamese Emperor, compiled the treatise Bách thế thông $k y$ thu 百世通紀書 (Scripture of the comprehensive chronicles of a hundred generations); this treatise was lost, but, according to a description found in a slightly later text, it contained a reconstruction of Chinese (?) chronology and a (retrospective?) calculation of eclipses. ${ }^{42}$

According to the conventional accounts, a large number of the books in Vietnamese governmental libraries were lost to fire or taken by the Chinese invaders in the late 14 th - early 15 th centuries. If, according to legends, the fire that occurred during the sack of the capital by the Chams in 1371 indiscriminately destroyed a number of unspecified libraries, the Chinese invaders who allegedly seized a large number of books and transported them to China most probably

42. See the Records of Dreams of the Old Man from the South (Vietnamese Nam ông mông luc 南翁夢錄, Chinese Nan weng meng lu) by Hồ Nguyên Trừng 胡元澄 (also known as Lê Trừng 黎澄, 1374?-1446?), the relevant excerpt reads: 其人通曉曆法, 嘗著

《百世通紀書》，上考堯甲辰，下至宋元，日月交蝕，星辰緾度，與古符合(This man [=Trần Nguyên Đán] comprehended and understood the methods of the calendar; [he] compiled the Scripture of the comprehensive chronicles of a hundred generations [which] started with the original [configuration of] constellations of [the mythical Chinese emperor] Yao and went down to the Song and Yuan [dynasties]. [He calculated (?)] solar and lunar conjunctions and eclipses, the degrees [= coordinates] of planets and stars on [their respective] orbits. [All these data (?)] fitted well with antiquity.); see also Knorozova 2009: 156-157. 
especially targeted texts seen as symbolically affirming the independence of the Vietnamese state, that is, first of all, local chronicles, calendars, astronomical and astrological texts. ${ }^{43}$

The search for Vietnamese materials related to astrology is also complicated by the composite structure of the extant documents; a number of the manuscript books preserved in libraries are collections of texts of different natures that may contain sections copied from astrological books. Several astrological treatises catalogued in Trần and Gros 1992 and Liu et al. 2002 contain appendices that sometimes consist of minor astrological texts with different titles often unrelated to each other and to the principal treatises (for examples, see below). Moreover, even when the title of a treatise coincides with that of a well-known Chinese astrological text, it may well be an abridgement or a variation on the theme of the Chinese prototype, or an edition with commentaries in Classical Chinese or in Nôm added by Vietnamese authors. This is why the list of primary astrological sources found in the bibliography below cannot be considered complete; nevertheless, it allows us to see, at least to a certain extent, which types of astrological texts were most frequently reproduced and commented upon.

In the next section I will briefly discuss the extant sources. The discussion is subdivided into two parts: firstly, I will introduce the three major systems of Chinese astrology and briefly present the extant Vietnamese treatises apparently influenced by them; secondly, I will, equally briefly, discuss the structure of a Vietnamese treatise based on a Chinese prototype.

\section{Three traditions of Chinese medieval astrology and their reception in Vietnam}

The three most influential traditions of Chinese astrology, represented in the curriculum of the Song dynasty School of Computation as the "three [astrological] schemes" or the "three cosmic boards" (san shi 三式), were the divinatory systems Tai yi 太乙, Qimen dunjia 奇門遁甲, and Liu ren六壬. ${ }^{44}$

43. Tran 1938: 43, n. 3; Cadière and Pelliot 1904: 619, n. 3.

44. Ho Peng Yoke (2003) suggests the following translation of the names of these three astrological techniques: (1) "Method of the Taiyi Deity" (p. 36), (2) "[Aligning] the Distinguished-Ones and the [auspicious] Gates [together with] concealing the [Wood] jia stem" (p. 84) while criticizing such more straightforward renderings as "Strange Gates Escaping Techniques" (p. 83), and (3) "The method of employing the six sexagenary cyclical numbers with the Yang Water stem" (p. 5) preferring it to the more literal "The art of the six Yang Waters" (p. 113). For the sake of brevity I will use the Chinese transliteration of these names below. 
(1) The Tai yi system. In China, this system was adopted by the Astrological Bureau during the Tang dynasty (618-907) and was used through the Song dynasty (960-1279). ${ }^{45}$ Yan Dunjie 嚴敦杰 (1917-1988) discovered that the divination techniques of this tradition already existed in the early 6th century AD. ${ }^{46}$ The foundational text of this tradition was the Taiyi jinjing shijing 太乙金 鏡式經 (Golden Mirror Manual for the Tai yi Cosmic Board) by Wang Ximing 王希明 (Tang dynasty), preserved (probably with later additions) in the 18th century Chinese collection Si ku quan shu 四庫全書. The divinatory procedure involved manipulation with a divinatory board (or, possibly, a diagram) which featured a central circle and four concentric circular layers subdivided into 16 sectors each. The first layer was filled with numbers from 1 to 4 and from 6 to 9 , forming, together with the number 5 in the central circle, a magic square; the first circular layer also contained 8 trigrams and some cyclical signs. The next layer contained names of "divine agents," and the third layer, names of Chinese provinces. ${ }^{47}$ The last layer was empty and was supposed to be filled during the process of divination. As Ho suggests, the applications of this method were mainly related to military affairs, yet there were also cases when the divination was concerned with natural phenomena, such as earthquakes, thunderstorms, and even eclipses. ${ }^{48}$

Among the extant Vietnamese texts there are two treatises directly related to this tradition: the Thái Ât Dị Giản Luc 太乙易簡錄 (Brief record [concerning divination according to the method] Tai Yi and [to the Book of] Changes) [A38] and the Thái Ât Thống Tông Bảo Giám 太乙統宗寶鑑 (Precious mirror of Unified Origins of the [methods of] Tai Yi) [A39]. The former treatise is credited to the authorship of the famous literatus Lê Quý Đôn 黎貴惊 (1726-1784). According to the biography of Lê Quý Đôn authored by Nguyễn Hữu Tạo 阮 有造 (who obtained the doctoral degree Tiến Sĩ 進士, Chinese jinshi, in 1844), Lê wrote three more astrological treatises, one of which, namely the Thái Ât Quái Vận 太乙卦運 (Circulation of Tai Yi [among] the trigrams), now lost, was apparently related to the same system of divination. ${ }^{49}$ As for the treatise Thái Ât Thống Tông Bảo Giám 太乙統宗寶鑑, it is possible that this book is a copy or

45. Ho 2003: 36 .

46. Ho 2003: 36-40: 171, n.3-4; Ho suggests that a recently unearthed divinatory instrument of the Han dynasty may have represented a rudimentary form of this technique (p. 41). See also Kalinowski 1991: 105, 542, n. 79, 568, n. 23.

47. This element of the divinatory scheme must apparently have been modified when transmitted to Vietnam.

48. Ho 2003: 66-68.

49. Tran 1937: 33. Two other treatises were related to the system of divination Liu ren; I will return to them below. Tran also mentions another literary work of Lê devoted to 
an abridgement of the Chinese treatise (reproduced in the Si ku quan shu 四庫 全書) of the same title by an obscure author of the Yuan dynasty (1279-1368), known under the pseudonym "Old Man from the Xiao Mountains" (Xiao shan lao ren 曉山老人). Several Chinese editions of this Chinese treatise exist, the earliest is a Ming dynasty manuscript and there are several editions dating from the Qing dynasty.

In China, the Tai yi system was preserved within the so-called tradition of "Numerical divination of Purple Rose and Dipper" (Ziwei doushu 紫微 $[=$ 薇]斗數). ${ }^{50}$ Ho Peng Yoke claimed that there were two branches of the latter tradition: one of them was a direct continuation of the Tai yi system, while the other, represented by a version of the treatise found in the Daoist Canon (Daozang 道藏), resulted from a synthesis of several astrological systems of Western origin. ${ }^{51}$ There exist seven Vietnamese texts belonging to this tradition: An tủ vi quốc ngũ ca 安紫微國語歌 [A1], Tủ Vi Đẩu Số紫微斗數 [A47], Tủ Vi Đẩu Số Giải Âm 紫微斗數解音 [A48], Tủ Vi Giải 紫微解 [A49], Tủ Vi Hà Lac Nhâm Thin Số 紫微河洛壬辰數 [A50], Tủ Vi Số紫微數 [A51], and Tủ Vi Thạp Nhị Cung Đoán Pháp Quốc Âm Ca 紫微十二宮斷法國音歌 [A52]. Four out of these seven treatises, namely, [A1, A47, A48, A52] are written in Nôm or contain commentaries in Nôm and were apparently intended for those readers who were not comfortable with classical Chinese.

divination (Tran 1937: 34); this text, titled Hai hội minh châu 海會明珠 and available when Tran was writing his article, is now lost.

50. Here the "Rose" is Rosa Multiflora (Chinese: wei 薇). Zi wei (Purple Rose) refers to a northern circumpolar asterism, see, for example, Ho 2003: 76.

51. Ho 2003: 74-82. 


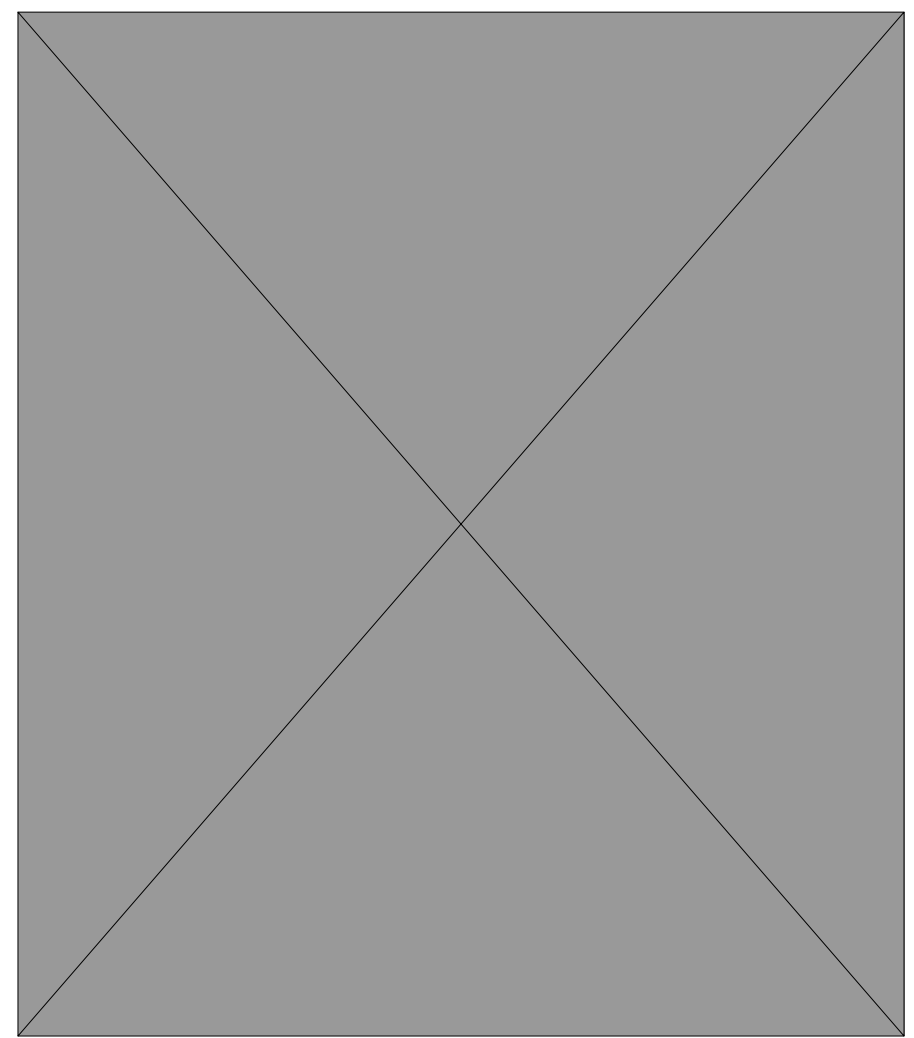

Fig. 2. A horoscope from the Tủ Vi Đẩu Số 紫微斗數

(Institute of Han-Nom Studies, call number VHb.163).

There exist 10 manuscript copies of [A47] (a horoscope from it is shown in Fig. 2); this large number of copies suggests that the treatise was rather popular among practitioners. Meanwhile, two of the seven texts, [A49] and [A50], are handwritten copies of unidentified Chinese printed originals. Unfortunately, none of these manuscript texts is dated. The titles of the treatises might seem to suggest that they were entirely devoted to only one system of divination; however, this is not necessarily the case: for example, the text [A1] contains an independent treatise Mã tiền bốc pháp 馬前卜法 [A24] as its last section.

(2) The Qimen dunjia system. Early mentions of the methods Qimen 奇門 and Dunjia 遁甲 can be found in the treatise Baopuzi 抱樸子authored by the famous Chinese scholar Ge Hong 葛洪 (283-343). A number of books apparently related to the Dunjia tradition are mentioned in the bibliographic chapters of 
the standard Chinese histories Hou Han shu 後漢書, Sui shu 隋書, Jiu Tang $s h u$ 舊唐書 and Xin Tang shu 新唐書, but none of these books is now extant. A text titled Huangting Dunjia yuan shen jing 黃庭遁甲緣身經 is found in juan 14 of the Daoist collection Yun ji qi qian 雲笈七籤 (Seven Tablets from Cloudy Book Depository) edited in the early 11 th century and preserved in the Daozang; however, the system described there was not one of the "three cosmic boards" used for instruction in the Song dynasty "School of Computations." 52 It appears that originally Qimen and Dunjia referred to two different systems that were combined by the 8 th century at the latest.

This tradition was apparently not very popular in Vietnam; I was able to locate only two manuscripts related to it, the Độn Giáp Kì Môn 遁甲奇門 [A13] and Tam Kì Bát Môn Độn Pháp 三奇八門遁法 [A36]. Both are compiled in classical Chinese by anonymous authors; the dates of their compilation are unknown. The former manuscript contains an appendix titled Chiêm Tinh Bốc Pháp 占星卜法 (Methods of divination on the basis of asterisms). However, it appears that a number of extant treatises preserved elements of the Qimen dunjia system combined with the third of the "cosmic boards" traditions, the Liu ren.

(3) The Liu ren system. The origin of the third Chinese "cosmic board" system of divination, Liu ren 六壬 (Vietnamese Luc Nhâm), goes back to the period antedating the Han dynasty (206 BC-AD 220), even though the first complete description of the method dates to the Tang dynasty (618-907) ${ }^{53} \mathrm{~A}$ detailed discussion of the method provided by the polymath Shen Gua 沈括 (or Shen Kuo, 1031-1095) in his Mengxi bitan 夢溪筆談 shows how much the system of Liu ren was interrelated with the calendar. ${ }^{54}$ In the process of divination a duodenary circular table (cosmic board) was supposed to be used; it could be substituted by the diviner's palm, which made the system more "portable," if compared with the two other systems. ${ }^{55}$

This tradition apparently enjoyed great popularity in Vietnam; I was able to locate the following treatises: Đại Luc Nhâm Đại Toàn 大六壬大全 [A11], Luc Nhâm 六壬 [A17], Luc Nhâm Đại Đọnn 六壬大遁 [A18, A19], Luc Nhâm Đại Độn Pháp 六壬大遁法 [A20], Luc Nhâm Kinh Vĩ Luợc 六壬經緯略 [A21], Luc Nhâm Quốc Ngũ 六壬國語 [A22], Luc Nhâm Tiện Lãm 六壬便覽 [A23], and Tân San Luc Nhâm Đại Độn Bí Truyền 新刊六壬大遁祕傳 [A35]. ${ }^{56}$ The first of

52. Ho 2003: 83-84.

53. Kalinowski 1983.

54. Ho 2003: 113-119.

55. Ho 2003: 137.

56. Tran 1937: 33 mentions two more treatises related to the tradition of Luc Nhâm (that is, Liu ren 六壬) authored by Lê Quý Đôn 黎貴悖 (see above): the Luc Nhâm Hội Thông 六 壬會通 (Tran translates this title as Notions générales de la science de la divination 
these texts [A11] is an adaptation of chapters (juan 卷) 4 and 5 of the Chinese treatise Liu ren da quan 六壬大全 (Great Compendium of the [works on the] Liu ren [method]) by the Chinese author of the Ming dynasty Guo Zailai 郭載騋 (dates unknown; active in the early 17th century); one of the extant copies also includes chapters (juan) 118 and 119 of the Chinese treatise Wubei zhi 武備志 (Records on Military Provisions, 1621) by Mao Yuanyi 茅元儀 (1594-1640). Manuscript [A19] contains two appendices titled Luc Nhâm Khởi Lẹ 六壬起例 (Examples for initiation in the Liu ren method) and Ngoc Truóng Đàm Binh Ca 玉帳談兵歌 (Stanzas discussing military [applications] of the Jade Canopy) explaining in Nôm the Luc Nhâm (that is, Liu ren 六壬) system of divination; these appendices are credited to the authorship of the famous literatus and high level governmental officer Phùng Khắc Khoan 馮克寬 (1528-1613) who was sent as ambassador to China in 1597 and returned in 1599. ${ }^{57}$ According to some sources, Phùng Khắc Khoan translated the Yijing into Vietnamese (that is, Nôm); ${ }^{58}$ this fact may be used to confirm his expertise in mantic literature as well as his interest in the translation of Chinese texts into Vietnamese, even though one cannot entirely rule out the possibility that the authorship of Phùng, the famous literatus and ambassador to China, was assigned to anonymous astrological texts only later to increase their importance. A text titled Binh gia yếu chi 兵家要旨 (Chinese: Bing jia yao zhi) (Essential indications for militaries), devoted to applications of divination for military purposes and supposedly authored by Phùng, is appended to the treatise [A22], while a short treatise titled Thiên Vận Bỉ Thu 天運秘書 (Chinese Tian yun bi shu), Secret scripture on heavenly cycles, featuring connections between meteorological phenomena and calendars, and also credited to Phùng's authorship, is appended

appliquée à la guerre, probably on the basis of its contents) and Luc Nhâm Tuyển Túy 六壬選粹 (Choix de principes essentiels de la science de la divination appliquée à la guerre, according to Tran); both treatises are not found in the catalogues Trần and Gros 1993, Liu et al. 2002, nor in the National Library of Vietnam.

57. His travel to China is mentioned in CM 1969:2832; it is dated to the fourth month of the 20th year of the Vietnamese Quang Hung 光興 era, 1578-1599, that is, 1697 (indicated in CM 1969 as the 25th year of the Chinese Wanli 萬曆 era, 1572-1620, that is, 1596). Phùng returned from China in the 12th month of the 21st year of the Quang Hung era, that is, in 1599 (mentioned as the 26th year of the Wanli era, that is, 1598), see CM 1969: 2847. On Phùng Khắc Khoan, see also Gaspardone 1934: 115-116; Tran 1938: 106-107, 117; Knorozova 2009: 244, n. 38; on his meeting with a Korean ambassador in Beijing, see Cheng 2009.

58. Tran 1938: 106-107. 
to the treatise Xin lüe tian shu 心略天樞 written by the famous Chinese scholar and astrologer Liu Bowen 劉伯溫 (Liu Ji 劉基, 1311-1375). ${ }^{59}$

\section{Processing Chinese texts: the example of the Ngọc Hạp Kí 玉匣記}

In this section I would like to demonstrate the complexity of the process of compilation of Vietnamese astrological texts on the basis of their Chinese prototypes. Let us consider the case of a group of treatises related to the tradition of the Chinese astrological compendium Yu xia ji 玉匣記 (Records from the Jade Chest). The titles of a number of Vietnamese texts contain the term Ngoc Hap 玉匣 (Jade Chest), namely, the Ngọc Hạp 玉匣 [A25], Ngọc Hạp Toản Yếu 玉 匣纂要 [A26], Ngọ Hạp toản yếu thông dụng 玉匣攢要通用 [A27], Tăng Bổ Tuyển Trạch Thông Thu Quảng Ngoc Hap Ki 增補選擇通書廣玉匣記 [A37], and Thông Thu Quảng Ngọ Hap Ki 通書廣玉匣記 [A44]. This tradition was apparently quite popular: the Library of the Institute of Hán-Nôm Studies holds 10 printed copies of [A25], one of them dated to 1876 and one to 1923; the treatises [A27], [A37] and [A44] were also printed. The authors of the catalogs Trần and Gros 1993 and Liu 2002 agree that these texts reproduce a Chinese original and credit the authorship of them to the Daoist immortal "Perfected Lord Xu" (許真君), that is, Xu Xun 許遜 (239-292/374?). ${ }^{60}$ The text of the Daozang entitled Xu zhen jun yu xia ji 許真君玉匣記 (Records from the Jade Chest of the Perfected Lord $\mathrm{Xu}$ ) with a preface of 1433 [YXJ], is, indeed, explicitly credited to his authorship. ${ }^{61}$ Was $\mathrm{Xu}$ Xun, famous mainly as a dragon-slayer and a pious son, also an expert in astrology? ${ }^{62}$ The question is probably not as relevant to the topic of this section as the following one: Was this text from the Daozang indeed reproduced in the above-mentioned Vietnamese treatises? A cursory analysis shows that the answer is in the affirmative, but the situation is far from being simple. The original text found in the Daozang under the title 玉匣記 (Records from the Jade Chest) technically contains three parts: (A) the

59. See also the voluminous mansucript Binh Pháp Tập Lược 兵法輯略 (Chinese Bing fa ji lüe) allegedly compiled by Liu Bowen (Liu Ji) and edited by Nguyễn Đức Uông 阮 德汪 (dates unknown), TG 246 (a microfilm copy of it is available in the library of the EFEO in Paris); this treatise is devoted to military applications of astrology.

60. For biographic data on Xu Xun as found in the Daozang and his cult, see Boltz 1987: 70-78.

61. For a short description see Ren 1991: 1170, no. 1467.

62. One text compiled no earlier than 1295 mentions Xu Xun as "Xu Taishi zhenjun" 許 太史真君, that is, Xu Xun is explicitly mentioned here as Great Astrologer taishi 太史 (Head of the Astrological Bureau, see Hucker 1985: 481, no. 6212); J. Boltz suggested "Perfected Lord Xu, the Grand Scribe" (1987: 75) 
text titled Zhu shen sheng dan ling jie ri qi 諸神聖誕令節日期 dating to the mid-15th century; (B) the above-mentioned Xu zhen jun yu xia ji 許真君玉匣 記 [YXJ]; and (C) the Fa shi xuan ze ji 法師選擇記 (Records on the choices [of auspicious days] by Masters of Dharma) [XZJ]. The relatively short initial section of part (C), hereafter C1 [XZJ: 325-326], dates to AD 627 and is followed by a very long "Postscript" (C2) [XZJ: 327-346] dating to 1488 and consisting of a large number of relatively short astrological texts. If we now look at the Vietnamese treatise Ngọc Hạp toản yếu thông dụng 玉匣攢要通用 [A27], we can see that part (A) is entirely omitted, a large portion of (B) is reproduced in the opening section of the Vietnamese treatise (pp. 2b-6b), and part (C1) is reproduced immediately after it (pp. 6b-9b); then follows a long section entitled (in Chinese) “Zhan san shi er gua ding ji xiong”占三十二掛定吉凶 (Divination [using] 32 hexagrams to determine good and bad luck, pp. 9b-19b) not found in the Daozang edition. Only after that is the section entitled (in Chinese) "Jin fu jing” 金符經 (Treatise on the Golden Talisman, pp. 19b-25a) reproduced from the Daozang text [XZJ: 331-334]. It is interesting that in the Daozang the subtitle of this section is missing (p. 331), and the fact that the compilers of the Vietnamese edition correctly identified the location of the title in their edition of the text strongly suggests that they had at their disposal a version of the treatise that was not based on the Daozang edition. How and when this alternative version of the treatise reached the Vietnamese diviners will probably remain unknown.

\section{Conclusions}

To study the history of the Vietnamese astrological tradition, several approaches appear equally plausible. An investigation of the extant written sources provided in the present paper is only one of them; another plausible methodology would be a study of the written reports of the Western missionaries active in Vietnam since the early 17th century, as well as of those by Western and Chinese travelers and merchants. For a study of the present-day situation, the results of recent anthropological field studies could be used. Each approach has its weak points. Numerous ancient documents are lost, and it is unknown to what extent the extant Hán-Nôm treatises represent the corpus of astrological works that circulated among Vietnamese astrologers from the 10th to the early 20th century; it is equally unknown how much the actual divinatory practices of those astrologers corresponded to written texts. If one studies the reports of missionaries, merchants and travelers, the rare mentions of indigenous practices of divination make it clear that their study was not central to the scholarly agenda of the missionaries and explorers, and, moreover, the rationale of divinatory 
practices as well as the relevant documents were never disclosed to them by the Vietnamese diviners. As for modern anthropologists, even those of them who have attempted to take a closer look at the actual practices of diviners nowadays were, in a large number of cases, not familiar with the historical antecedents of the phenomena they observed, in particular with the divinatory texts in Hán-Nôm.

In this paper I briefly described the institutional setting of the first centuries of the independent state-sponsored Vietnamese astrological tradition, and provided the results of a cursory inspection of a small part of the extant astrological materials. All the discussed materials turned out to be either copies of Chinese texts (sometimes altered or abridged) or works based upon Chinese prototypes. The history of their transmission to Vietnam is obscure; the majority of the extant Vietnamese texts are not dated, and those dated were produced (usually, printed) relatively late. Very often the authorship of the texts is unknown; in some cases, the dates of life of the putative authors suggest that the transmission may have taken place rather early, as in the case of the treatises credited to the authorship of Phùng Khắc Khoan 馮克寬, yet there is always a possibility that the name of the presumed author, usually a famous scholar or a high-level functionary, was associated with an anonymous text only after the scholar's lifetime. However, as the history of astrological institutions demonstrates, astrology certainly started being practiced for the purposes of the Vietnamese state as early as the 11th century; unfortunately, it remains unknown how and when the earlier Chinese astrological texts found their way to the breakaway province after the 10th century, and what they were exactly. In the modern libraries holding collections of Hán-Nôm books all the astrological texts are put together, which might appear to suggest that astrology was a discipline practiced by just one group of experts; however, one can argue that the transmission of astrological texts and expertise went from China to Vietnam through a number of channels, and, on both sides, the social groups involved in this process ranged from the imperial astrologers to countryside fortune-tellers.

\section{REFERENCES}

\section{Primary sources}

A. Extant Vietnamese astrological treatises

[The texts in this section are ordered alphabetically according to the Vietnamese readings of their titles. For each text I provide the Vietnamese reading of its title, its original title in Hán-Nôm, its Chinese reading (in pinyin), and a tentative translation (which in some cases may not be fully satisfactory). Each text has 
a reference number used in the body of this paper; for example, A35 refers to the text listed in this section under number 35. The dates of compilation and production, the name of the author(s) are mentioned in the cases when they are known; if they are not provided, it means that they remain unknown to me. For each text, references are provided to the catalogues Trần and Gros 1993 (starting with the letters TG) and Liu et al. 2002 (starting with the letter L); in the cases when a text is found in the National Library of Vietnam, I provide the call number from the catalogue of this library starting with the letters BNV.]

1. An tư vi quốc ngũ ca 安紫微國語歌 (An Zi wei guo yu ge). (Explanations of the [numerical divination on] Purple Rose [and Northern Dipper] in poems [written in] national language [=Nôm]). BNV R.293.

2. Bốc PhệChính Tông 卜筮正宗 (Bu shi zheng zong) (Orthodox origin of the [methods of divination] bu and shi). 1848-1859. By Master Cổ La (Chinese: Gu Luo) 古羅 先生 (dates unknown). TG 277; L 2470.

3. Chiêm Bốc Tạp Nghiệm 占卜雜驗 (Zhan bu za yan) (Miscellaneous practices of divination). TG 440; L 2491.

4. Chiêm Luận Sụ̂ Niên Nguyệt Nhật Thì Tích 占論事年月日辰跡 (Zhan lun shi nian yue ri chen ji) (Divination on the basis of the years, months, days, and constellations [= hours] [of birth]). TG 442; L 2492.

5. Chiêm Nhật Nguyệt Cát Hung Đồ 占日月吉凶圖 (Zhan ri yue ji xiong tu) (Diagrams for divination concerning good luck and bad luck [on the basis] of days and months). TG 443; L 2484.

6. Chiêm Phu Thê Giá Thú Hơp Hôn Cát Hung Số 占夫妻嫁娶合婚吉凶數 (Zhan fu qi jia qu he hun ji xiong shu) (Divination on good luck and bad luck of marriages). TG 444; L 2493.

7. Chiêm Thiên Văn Chu Loại Đẳng Tinh Cát Hung Đồ 占天文諸類等星吉凶圖 (Zhan tianwen zhu lei deng xing jixiong tu) (Diagrams for divination on celestial figures, all classes and ranks of celestial bodies, concerning good luck and bad luck). TG 447; L 2485.

8. Chiêm Thiên Văn Loại 占天文類 (Zhan tian wen lei) (Categories of divination on celestial patterns). TG 448; L 2486.

9. Chiêm Thiên Văn Thu 占天文書 (Zhan tian wen shu) (Scripture on divination on celestial patterns). TG 449; L 2487.

10. Cưu Thiên Huyền Nũ Toán Pháp 九天玄女算法 (Jiu tian xuan nü suan fa) (Counting methods of the Obscure Maiden of Nine Heavens). TG 640; L 2471.

11. Đại Luc Nhâm Đại Toàn 大六壬大全 (Da Liuren daquan) (Great compendium of the great Six [signs] ren). Alternative title: Đại Luc Nhâm Đại Toàn 大六壬大遁 (Da Liuren dadun) ([Methods] of Great Evasion and of the great Six [signs] ren). By Guo Zailai 郭載轪 of the Ming dynasty. TG 823; L 2472.

12. Diệu Tiên Kinh 曜仙經 (Yao xian jing) (Hemerological treatise of [Daoist] immortals (?)). TG 736; L 2504. 
13. Độn Giáp Kì Môn 遁甲奇門 (Dun jia qi men) ([Methods] of dunjia and qimen). ${ }^{63}$ TG 1094; L 2500.

14. Khâm Định Hiệp Kỉ Biện Phuong 欽定協紀辨方 (Qin ding xie ji bian fang) ([Scripture on] unifying eras and separating positions, approved by the Emperor). Alternative titles: Hiẹp Biện協辨 (Xie bian) (Unification and separation); Tạp Chiêm 雜占 (Za zhan) (Miscellaneous [methods of] divination). TG 1652; L 2498.

15. Linh Văn Thắng Lãm Kinh Tổng Luận 靈文勝覽經總論 (Ling wen sheng lan jing zong lun) (Integral discussion [based upon] inspection of treatises in "script of spirits"). TG 2010; L 2506.

16. Luc Giáp Toàn Thu 六甲全書 (Liu jia quan shu) (Complete scripture concerning the [method of] Six [signs] jia). TG 2075; L 2507.

17. Luc Nhâm 六壬 (Liu ren) (Six [signs] ren). TG 2077; L 2476.

18. Luc Nhâm Đại Độn 六壬大遁 (Liu ren da dun) ([The methods of] Six [signs] ren and of Great Evasion). TG 2078; L 2508.

19. Luc Nhâm Đại Độn 六壬大遁 (Liu ren da dun) ([The methods of] Six [signs] ren and of Great Evasion). TG 2079; L 2477.

20. Lục Nhâm Đại Độn Pháp 六壬大遁法 (Liu ren da dun fa) (The methods of Six [signs] ren and of Great Evasion). TG 2080; L 2478.

21. Luc Nhâm Kinh Vĩ Lược 六壬經緯略 (Liu ren jing wei lüe) (Abridgement of the Canon and Apocrypha on the Six [signs] ren). TG 2082; L 2479.

22. Luc Nhâm Quốc Ngũ 六壬國語 (Liu ren guo yu) ([The methods of] Six [signs] ren [explained in] national language [= Nôm]). TG 2083; L 2480.

23. Lục Nhâm Tiện Lãm 六壬便覽 (Liu ren bian lan) (Reader's digest on Six [signs] ren). TG 2084; L 2481.

24. Mã tiền bốc pháp 馬前卜法 (Ma qian bu fa) (Divination methods [concerning "pouring water] in front of [one's] horse"). ${ }^{64}$

25. Ngoc Hap 玉匣 (Chinese: Yu xia) ([Records from] the Jade Chest). By Perfected Lord Xu (許真君) [=Xu Xun 許遜]. TG 4744; L 2511.

26. Ngọc Hạp Toản Yếu 玉匣纂要 (Yu xia zuan yao) (Essentials of the compilation from the Jade Chest). TG 4745; L 2483.

27. Ngọ Hạp toản yếu thông dụng 玉匣攢要通用 (Yu xia zan yao tong yong) (Comprehensive use of the essentials of the collection from the Jade Chest). Printed in 1926. BNV R.2227.

63. Ho Peng Yoke's (adapted) translation of the title would read: "Concealing the (Wood) Jia stem (together with aligning) the Distinguished-Ones and the (auspicious) Gates" (Ho 2003: 84).

64. The title contains an allusion to the Chinese chengyu (idiomatic expression) ma qian po shui 馬前潑水 (“To pour water in front of [one's] horse”), meaning the impossibility of reunification for a divorced couple, and coming from the anonymous Chinese opera of the Yuan or early Ming dynasty Zhu Taishou feng xue yu qiao ji 朱太守風雪漁樵記 (Governor Zhu going fishing and cutting wood in strong wind and snow). I am thankful to Lin Hung-Chun 林虹君 for her explanations of the meaning and etymology of this chengyu. 
28. Ngoc Truóng Huyền Co 玉帳玄機 (Yu zhang xuan ji) ([Methods of] Obscure Pole and Jade Canopy). TG 2354; L 2488.

29. Ngọc Truóng Huyền Co Bí Độn Thu Pháp 玉帳玄機祕遁書法 (Yu zhang xuan ji bi dun shu fa) (Methods of the scripture on secret escape [according to the] [treatise on] Obscure Pole and Jade Canopy). TG 2355; L 2489.

30. Ngọc Truóng Huyền Co Bí Pháp 玉帳玄機祕法 (Yu zhang xuan ji bi fa) (Secret methods of Obscure Pole and Jade Canopy). TG 2356; L 2490.

31. Quỷ Cốc Đại Định Hoàng Tuyền Số 鬼谷大定黃泉數 (Guigu da ding huang quan shu) (Numerical [divination] on the [return to?] Yellow Sources, majestically established by the [master] Guigu). TG 2912; L 2496.

32. Quỳnh Lâm Huyết Hải Thu 瓊林血海書 (Qiong lin xue hai shu) (Scripture of Forest of Jasper and Sea of Blood). TG 2914; L 2505.

33. Sách Coi Số 冊 $[\ldots]^{65}$ 數 (Ce [...] shu) (Numerical [divination] according to [...] books). TG 2921; L 2494.

34. Số Pháp Thu 數法書 (Shu fa shu) (Scripture on methods of numerical [divination]). TG 2966; L 2502.

35. Tân San Luc Nhâm Đại Độn Bỉ Truyền 新刊六壬大遁祕傳 (Xin kan Liu ren da dun bi chuan) (Newly printed [sic] secret tradition of the [methods of] Six [signs] ren and of Great Evasion). A manuscript dated 1883. TG 3192; L 2501.

36. Tam Kì Bát Môn Độn Pháp三奇八門遁法 (San qi ba men dun fa) (Methods of Evasion [using] Three Strange [Agents] and Eight Gates). TG 3078; L 2473.

37. Tăng Bổ Tuyển Trạch Thông Thu Quảng Ngọc Hạp Ki 增補選擇通書廣玉匣 記(Zengbu xuanze tongshu guang Yu xia ji) (Almanac book on the choice [of auspicious days] [combined with] the extended Records from the Jade Chest, with additions and complements). Alternative title: Tăng Bổ Tuyển Trạch Thông Thu Quảng Ngoc Hap Ki 選擇通書廣玉匣記 (Xuanze tongshu guang Yu xia ji) (Almanac book on the choice [of auspicious days] [combined with] the extended Records from the Jade Chest). Prints of 1876, 1920, and 1923. By Perfected Lord Xu (許真君) [= Xu Xun 許遜 (239-374)]. TG 4855; L 2518; BNV R.60.

38. Thái Ât Dị Giản Luc 太乙易簡錄 (Tai Yi yi jian lu) (Brief record [concerning divination according to the method of] Tai Yi and [to the Book of] Changes). Compiled in 1766 by Lê Quý Đôn 黎貴惊 (1726-1784). TG 3290; L 2475.

39. Thái Ât Thống Tông Bảo Giám 太乙統宗寶鑑 (Tai yi tong zong bao jian) (Precious mirror of Unified Origins of the [methods of] Tai Yi). TG 3291; L 2482.

40. Tham Bình Bí Quyết Kim Tỏa Ngân Chủy Ca 參評祕訣金鎖銀匙歌 (Can ping bi jue jin suo yin shi ge) (Stanzas on compared and critically [evaluated] secret prescriptions of Golden Lock and Silver Key). TG 4889; L 2514.

41. Thần Lịch Tạp Ki Pháp 神歷雜忌法 (Shen li za ji fa) (Various methods of malevolent [days according to] spirits' itineraries). TG 3388; L 2521.

42. Thiên Văn Thể 天文體 (Tian wen ti) (Structure (?) of celestial patterns). TG 3543; L 2474.

65. An unidentified Nôm character. 
43. Thông Thu Chính Quyển 通書正卷 (Tong shu zheng quan) (Almanac: an orthodox volume). TG 3601; L 2497.

44. Thông Thu Quảng Ngoc Hạ Ki 通書廣玉匣記 (Tongshu guang Yuxia ji) (Almanac book [combined with] the extended Records from the Jade Chest). Printed in 1876. TG 4926; L 2513.

45. Tiền Định Lập Thành 前定立成 (Qian ding li cheng) (Ready-made [manual for identification of] predestinations). TG 3724; L 2495.

46. Toát Kim Bốc Pháp 撮金卜法 (Cuo jin bu fa) (Divination methods [worth one] cuo of gold). TG 3797; L 2524.

47. Tủ Vi Đẩu Số 紫微斗數 (Zi wei dou shu) (Numerical [divination according to the method of] Purple Rose and Dipper). TG 4992; L 2515.

48. Tủ Vi Đẩu Số Giải Am 紫微斗數解音 (Zi wei dou shu jie yin) (Explanations and [correct] reading of the Numerical [divination according to the method of] Purple Rose and Dipper). TG 4102; L 2509.

49. Tủ Vi Giải 紫微解 (Zi wei jie) (Explanations of [the method of] Purple Rose). TG 4993; L 2516.

50. Tủ Vi Hà Lạc Nhâm Thìn Số 紫微河洛壬辰數 (Zi wei He Luo ren chen shu) (Numerical [divination according to the methods] of Purple Rose, He [tu] and Luo [shu], [Six (?) signs] ren and constellations). TG 4995; L 2517.

51. Tủ Vi Số 紫微數 (Zi wei shu) (Numerical [divination] of the Purple Rose). TG 4103; L 2499.

52. Tủ Vi Thập Nhị Cung Đoán Pháp Quốc Âm Ca 紫微十二宮斷法國音歌 ( $Z i$ wei shi er gong duan fa guo yin ge) (Rhymed methods of making decisions [on the basis of the methods] Purple Rose [and] Twelve Palaces [described] in national language [= Nôm]). TG 4104; L 2510.

53. Tuyển Trạch Thông Thu Đại Toàn 選擇通書大全 (Xuanze tongshu daquan) (Selected [topics] from the great compendium of almanacs). A MS copy dated 1880. TG 4044; L 2503.

B. Vietnamese Chronicles

CM 1969 - Trần VănVi 陳文為 et al. (eds.). Khâm Định Việt Sủ Thông Giám Cương $M u c$ 欽定越史通鑑綱目 (Imperially Commissioned Itemized Summaries of the Comprehensive Mirror of Viet History). Taipei: Guoli zhongyang tushuguan.

SL 1936 - [Anon.] [Đai ] Việt sử lược [大]越史略. Shanghai: Shangwu yinshuguan.

TT 1984 - Chen Jinghe 陳荊和 (ed.), 校合本大越史記全書 (A critical edition of the Đại Việt sủ ký toàn thu 大越史記全書), Tokyo: Institute for Advanced Studies on Asia, University of Tokyo (東京大学東洋文化研究所), 3 vols., 1984-1986.

C. Other primary materials

KTG - Khâm Thiên Giám 欽天監 (The Directorate of the Veneration of Heaven). A manuscript dated 1930 preserved in the Institute of Hán-Nôm Studies, Hanoi; call number VHv. 1261. 
LHT - Lê Công Hành Trạng 黎公行狀 (A biography of Mr. Lê [Quý Đôn]). A manuscript preserved in the Institute of Hán-Nôm Studies, Hanoi; call number A.43.

XZJ - Fa shi xuan ze ji 法師選擇記 (Records on the choices [of auspicious days] by Masters of Dharma). In Zhengtong Daozang 正統道藏, Taibei: Hsin Wen Feng Publishing Company, 1977, vol. 60: 325-346.

YXJ - Xu zhenjun Yuxia ji 許真君玉匣記 ('Records from the Jade Chest' by Perfected Lord Xu [= Xu Xun 許遜]). In Zhengtong Daozang 正統道藏, Taibei: Hsin Wen Feng Publishing Company, 1977, vol. 60: 321-324.

\section{Secondary sources and translations}

ArHem, Nikolas (2009). In the Sacred Forest: Landscape, Livelihood and Spirit Beliefs among the Katu of Vietnam. SANS Papers in Social Anthropology 10, Gothenburg, University of Gothenburg.

Boltz, Judith M. (1987). A survey of Taoist literature: Tenth to Seventeenth Centuries. Berkeley, University of California, Institute of East Asian studies.

Cadière, Léopold et Pelliot, Paul (1904). "Première étude sur les sources annamites de l'histoire d'Annam." Bulletin de l'École française d'Extrême-Orient, t. 4: 617671.

Chapuis, Oscar (1995). A History of Vietnam: from Hong Bang to Tu Duc. Westport, Greenwood Press.

CHENG Wing-sheung 鄭永常 (June 2009). “Yi ci qiyi de shi zhi waijiao: Feng Kekuan yu Li Suiguang zai Beijing de jiaohui 一次奇異的詩之外交: 馮克寬與李睟 光在北京的交會” (A Strange Case of Diplomacy via Poetry: The Encounter of Phung Khac-Khoan and Yi Su-Gwang in Beijing). Taiwan gudian wenxue yanji jikan 臺灣古典文學研究集刊, vol. 1: 345-347, 349-372.

Coulet, Georges (1926). Les Sociétés secrètes en terre d'Annam. Saïgon, Ardin.

Coulet, Georges (1929). Cultes et religions de l'Indochine annamite. Saïgon, Ardin.

Dumoutier, Gustave (1899). “Études d'ethnographie religieuse annamite: Sorcellerie et

Divination." Actes du XI Congrès international des Orientalistes (1897), Paris, tome II: 275-409.

Dumoutier, Gustave (nov.-déc. 1914). "L'astrologie considérée plus spécialement dans ses applications à l'art militaire.” Revue Indochinoise: 456-475.

Dumoutier, Gustave (July-Aug. 1915). "L'astrologie chez les Annamites: ses applications a l'art militaire." Revue Indochinoise: 101-126.

Fedorin, Andrei [Федорин, Андрей Львович] (2009). “Лунно-солнечный календарь на Дальнем Востоке: вьетнамский вариант" (Luni-Solar calendar in the Far East: a Vietnamese version). Проблемы Дальнего Востока, nо. 4: 158-162.

Friedsam, Manfred (2003). "L'enseignement des mathématiques sous les Song et Yuan."

In C. Despeux and C. Nguyen Tri (eds.), Education et instruction en Chine, vol. 2 (Les formations spécialisées), Paris/Louvain, Éditions Peeters: 49-68.

Gaspardone, Emile (1934). "Bibliographie Annamite.” BEFEO, fasc. 1: 1-173.

HAN Qi 韓琦 (1991). “Zhong Yue lishi shang tianwenxue yu shuxue de jiaoliu 中越 歷史上天文學與數學的交流 (The interaction between Chinese and Vietnamese 
astronomy and mathematics in the past)." Zhongguo keji shiliao 中国科技史料, vol. 12.2: 3-8.

Ho Peng Yoke (1964). "Natural phenomena recorded in the Đại Việt sủ ký toàn thu, an early Annamese historical source." Journal of the American Oriental Society, vol. 84.2: 127-149.

Ho Peng Yoke (2003). Chinese Mathematical Astrology: Reaching out to the Stars. London and New York, RoutledgeCurzon.

Huard, Pierre, et Durand, Maurice (1954). Connaissance du Viet-Nam. Paris/Hanoi, Imprémerie Nationale/École Française d'Extrême-Orient.

HuCKer, Charles O. (1985, repr. 1988). A Dictionary of Official titles in Imperial China. Taibei, Southern Materials Center (reprint of 1988; originally printed by Stanford University Press in 1985).

KaLinowsKi, Marc (1983). "Les instruments astro-calendriques des Han et la méthode Liu Ren." Bulletin de l'École française d'Extrême-Orient, t. 72: 309-419.

Kalinowski, Marc (1989). "La littérature divinatoire dans le Daozang." Cahiers d'Extrême-Asie, vol. 5: 85-114.

Kalinowski, Marc (tr.) (1991). Cosmologie et divination dans la Chine ancienne. Le Compendium de Cinq Agents (Wuxing dayi, $v I^{e}$ siècle). Paris, EFEO.

Kalinowski, Marc (ed.) (2003). Divination et société dans la Chine médiévale. Paris, Bibliotheque Nationale de France.

Knorozova, Ekaterina [Кнорозова, Екатерина Юрьевна] (2009). Странствия в бесконечном (Wandering in the infinite). Sankt-Peterburg, BRAN \& Alfaret Publishers.

LÊ, Alexandre (1995). Étude du Nôm, écriture idéographique de la langue Vietnamienne: son histoire, sa structure et sa valeur littéraire. Mémoire de D.R.E.A. de Vietnamien. Paris, INALCO (unpublished thesis).

LeE, Thomas H.C. (1985). Government Education and Examinations in Sung China. Hong Kong, The Chinese University Press, and New York, St. Martin's Press.

Liu Chun-Yin 劉春銀, Wang Xiaodun 王小盾, Trần Nghĩa 陳義 (2002). Yuenan HanNan wenxian mulu tiyao 越南漢喃文獻目錄提要 (Annotated catalogue of HánNôm literary materials). Taibei, Academia Sinica.

MArr, David G. (1981). Vietnamese Tradition on Trial, 1920-1945. Berkely etc., University of California Press.

Morgan, Carole (1980). Le Tableau du bouf du printemps. Étude d'une page de l'almanach chinois. Paris, Collège de France, Institut des Hautes Etudes Chinoises.

Morgan, Carole (1987). "La divination d'après les croassements des corbeaux dans les manuscrits de Dunhuang." Cahiers d'Extrême-Asie, vol. 3: 55-76.

NGUYẼ̃N Đình Hoà (1959). "Chữ Nôm, the Demotic System of Writing in Vietnam." Journal of the American Oriental Society, vol. 79, no. 4: 270-274.

NGUYẼ̃ Đình Hoà (1990). "Graphemic borrowing from Chinese: the case of chũ nôm, Vietnam's demotic script." Bulletin of the Institute of History and Philology, Academia Sinica [Taiwan], 61: 383-432.

NguYen Van Huyen (2002). The Ancient Civilization of Vietnam. Hanoi, The Gioi. 
Osborne, Milton E. (1997, repr. of 1969). The French Presence in Cochinchina and Cambodia: Rule and Response (1859-1905). Bangkok, White Lotus Press [first published by Cornell University in 1969].

PApIn, Philippe (2001). Histoire de Hanoi. Paris, Fayard.

PoIsson, Emmanuel (2004). Mandarins et subalternes au nord du Viêt Nam (18201918) - une bureaucratie à l'épreuve. Paris, Maisonneuve et Larose.

Polyakov, Aleksei [Поляков, Алексей Борисович] (tr.) (1980). Краткая история Вьета. Вьет шы льюк (Brief history of Viet. The Việt sử luợc). Moscow, Nauka.

REN Jiyu 任繼愈 et al. (eds.) (2nd ed. 1995). Daozang tiyao 道藏提要 (Annotations of the Daozang). Beijing, Zhongguo shehui kexue chubanshe.

Sмiтн, Richard J. (1991, repr. 1993). Fortune-tellers and Philosophers. Divination in Traditional Chinese Society. Boulder, Westview Press; reprinted Taipei, SMC Publishing Inc.

Tran Van Giap (1983). "Les chapitres bibliographiques de Le-qui-Don et de Phan-huyChu." Bulletin de la Société des Études Indochinoises, Saigon, Testelin, Nouvelle série, t. 13, no. 1: 13-217.

Tràn Nghĩa et Gros, François (eds.) (1993). Catalogue des livres en Hán-Nôm. Hanoi, Nha xuat ban khoa hoc xa hoi/Edition [des] sciences sociales.

Trinh Van Thao (1995). L'École française en Indochine. Paris, Karthala.

VÃN An Vi (2008). “A Thái Divination Kit in the Vietnam Museum of Ethnology." Asian Ethnology, vol. 67, no. 2: 257-269.

VARGYAS, Gábor (2004). “Thuật Tiên Tri trong Lễ Lên Đồng của Người Bru” [Divination in Bru Shamanism]. In Ngô Đức Thịnh (ed.), Đạo Mẫu và các Hình Thức Shaman Trong Các Tộc Người ở Việt Nam và Châu Á [Mother Goddesses and Some Shamanistic Forms in Ethnic Groups in Vietnam and Asia]. Hanoi, Nhà xuất bản Khoa học xã hội [Social Sciences Publishers]: 537-548.

Volkov, Alexei (2008). "Traditional Vietnamese Astronomy in Accounts of Jesuit Missionaries." In L. Saraiva and C. Jami (eds.), History of Mathematical Sciences, Portugal and East Asia III: The Jesuits, the Padroado and East Asian Science (1552-1773), Singapore etc., World Scientific: 161-185.

Volkov, Alexei (2009). "Mathematics and Mathematics Education in Traditional Vietnam." In E. Robson and J. Stedall (eds.), Oxford Handbook of the History of Mathematics, Oxford, Oxford University Press: 153-176.

VolKov, Alexei (2012). "Argumentation for State Examinations: Demonstration in Traditional Chinese and Vietnamese mathematics." In K. Chemla (ed.), The History of Mathematical Proof in Ancient Traditions, Cambridge, Cambridge University Press: 509-551.

Whitmore, John. K. (1995). "Cartography in Vietnam," in J. B. Harley and David Woodward (eds.), The History of Cartography, vol. 2, book 2: 478-508. 